\title{
Screening of winery and olive mill wastes for lignocellulolytic enzyme production from Aspergillus species by solid-state fermentation
}

\author{
José Manuel Salgado • Luís Abrunhosa • \\ Armando Venâncio • José Manuel Domínguez • \\ Isabel Belo
}

Received: 19 June 2013 /Revised: 24 September 2013 / Accepted: 24 September 2013 / Published online: 19 October 2013

(C) Springer-Verlag Berlin Heidelberg 2013

\begin{abstract}
Wastes from olive oil and wine industries (as exhausted grape marc, vineshoot trimmings, two-phase olive mill waste, vinasses, and olive mill wastewater) were evaluated for lignocellulolytic enzyme production (as endocellulases, endoxylanases, and feruloyl esterases) by solid-state fermentation (SSF) with Aspergillus niger, Aspergillus ibericus, and Aspergillus uvarum. To study the effect of different solid medium composition and time in enzyme production, a Plackett-Burman experimental design was used. Variables that had a higher positive effect in lignocellulolytic enzyme production were urea, time, and exhausted grape marc. The maximum values of enzymatic activity per unit of substrate dry mass were found with $A$. niger for feruloyl esterase. Enzymatic extracts from SSF with $A$. niger achieved maximum feruloyl esterase activity $(89.53 \mathrm{U} / \mathrm{g})$ and endoxylanase activity (3.06 U/g) and with A. uvarum for endocellulase activity $(6.77 \mathrm{U} / \mathrm{g})$. The enzyme cocktails obtained in the SSF extracts may have applications in biorefinery industries.
\end{abstract}

Keywords Olive mill wastes · Winery wastes · PlackettBurman · Solid-state fermentation · Lignocellulolytic enzymes

\footnotetext{
J. M. Salgado $\cdot$ L. Abrunhosa $\cdot$ A. Venâncio $\cdot$ I. Belo $(\bowtie)$ IBB - Institute for Biotechnology and Bioengineering, Centre of Biological Engineering, University of Minho, Campus de Gualtar, 4710-057 Braga, Portugal

e-mail: ibelo@deb.uminho.pt

\section{J. M. Domínguez}

Department of Chemical Engineering, Sciences Faculty, University of Vigo (Campus Ourense), As Lagoas s/n, 32004 Ourense, Spain
}

\section{Introduction}

Since the last two decades, lignocellulolytic enzymes (LCEs) are gaining enormous attention for their potential in biotechnology processes [1]. Principal LCEs are cellulases, hemicellulases, ligninases, and pectinases. LCEs are used in saccharification processes, for the subsequent production of ethanol by fermentation. Among the proposal to obtain simple sugars, they have applications on bioremediation processes and in the paper, textile, chemical, and food industries [1].

In biorefinery processes, LCEs are involved in different fractionation steps due to their ability to degrade lignin, cellulose, and hemicellulose from lignocellulosic materials. However, the use of enzymes increases the costs of these processes. LCE produced by submerged fermentation is expensive, about US\$0.4-0.6/gal ethanol [2]. Cellulase cost can be assumed to be US $\$ 0.25 / \mathrm{gal}$ of produced ethanol [3]. Therefore, the exploitation of agro-industrial wastes as a low-cost substrate for the production of enzymes can contribute to make those processes more profitable. In addition, a costeffective enzyme system should contain balanced activities of cellulases and hemicellulases to reduce the cost of bioethanol production [4].

Winery and olive mill wastes are commonly generated in Mediterranean countries. Several wastes from these industries are of lignocellulosic nature such as vineshoot trimmings (VTS), exhausted grape marc (EGM), and two-phase olive mill waste (TPOMW). The use of agro-industrial residues to produce high-value products and energy, in biorefinery concept, is an alternative to manage these wastes. Thus, they could be suitable substrates for LCE production by filamentous fungi in solid-state fermentation (SSF). Most commercial LCEs are currently produced by submerged fermentation [5]. However, SSFs are considered optimal for enzyme production 
because it may reach higher production yields than submerged fermentations. Besides, it is better because of its operational simplicity, low-energy requirements, simple cultures, and simple design bioreactors [6]. Compared with submerged fermentation, SSF enzymatic complexes showed a greater efficiency in lignocellulose saccharification [7]. Due to these facts, SSF can be an alternative technology for LCE production, using filamentous fungi that produce an optimal enzyme complex for the degradation of the host lignocellulose [2]. Lignocellulosic materials act as both the carbon source and as an inducer for LCE enzyme production [8]. In addition, SSF with fungi can be used as biological pretreatment to enhance enzymatic hydrolysis [9].

SSF is well adapted to the metabolism of fungi, so are the microorganisms most commonly in SSF processes [10]. Fungi produce a complete set of cellulases, cellobiohydrolases (EC 3.2.1.91), endoglucanases (EC 3.2.1.4), and $\beta$-glucosidases (EC 3.2.1.21), that are necessary to efficiently hydrolyse cellulose [11]. To this, a synergistic action of these enzymes is required to complete the hydrolysis of cellulose [12]. Cellulases carried out the hydrolysis of cellulose by breaking $\beta-1$, 4-glucosidic bonds. Endocellulases can hydrolyze these links internally in the cellulase chains, whereas cellobiohydrolases act at the end of the chains. The products of these enzymes are disaccharides or oligosaccharides which are hydrolyzed by $\beta$ glucosidases. Fungal strains that produce cellulases are mainly comprised of Trichoderma, Aspergillus, Penicillium, and Fusarium genera [4]. Aspergillus niger are frequently used to produce cellulases $[12,13]$. However, production of cellulases by Aspergillus uvarum and Aspergillus ibericus has not been studied. A. uvarum is morphologically close to Aspergillus japonicus [14]. This species has been used to produce cellulases by SSF of different agro-industrial wastes [14-16].

Among cellulase production, fungi can produce hemicellulases which are a diverse group of enzymes due to the heterogeneity of hemicelluloses. These enzymes improve the hydrolysis of cellulose by exposing their fibers, thus making them more accessible to hydrolysis by cellulases [17]. Xylanases are glycosidases $(O$-glycoside hydrolases, EC 3.2.1.x) which catalyze the hydrolysis of 1,4- $\beta$-D-xylosidic linkages in xylan [18]. Endoxylanases can hydrolyse $\beta-1,4$ links in xylan chains to oligomers which are hydrolyzed to xylose by $\beta$-xylosidases. Other enzymes such as $\beta$-mannoses, arabinofuranosidases, and $\alpha$-L-arabinases can act depending on hemicellulose composition. Endoxylanases are much more common than $\beta$-xylosidases [19]. Some genera that produce xylanases include the Aspergillus, Trichoderma, Streptomyces, Phanerochaetes, and Chytridiomycetes [18]. On an industrial scale, xylanases are produced by Aspergillus spp. [20]. Owing to Aspergillus secretions at high concentrations, a large variety of hemicellulases work synergistically [17].

Feruloyl esterases (FAEs, EC 3.1.1.73), also known as ferulic acid esterases, are another type of hemicelluloses; they are a subclass of carboxylic acid esterases (EC 3.1.1.1). FAEs are capable of releasing the phenolic acids such as ferulic and $p$-coumaric acid and their dimers. It has been demonstrated that FAEs act in synergy with xylanases by cleaving diferulic bridges between xylan chains, opening the structures, and releasing lignin [21]. In industries, A. niger FAEs are used for ferulic acid extraction from agro-industrial wastes [22]. Besides, FAEs are used in pulp and paper industry for lignin removal from cellulose [23]. In the processes of saccharification of lignocellulosic materials, combined treatment with cellulases, xylanases, and FAEs allows the use of lower quantities of enzymes and reduces the cost of the process [11]. Therefore, it may be interesting to obtain enzymatic extracts with these activities. In addition, production of LCE by $A$. ibericus and A. uvarum has been reported.

In the present work, we evaluate different wastes from olive oil and wine industries, TPOMW, EGM, VT, vinasses, and olive mill wastewater (OMWW), for endocellulase, endoxylanase, and FAE production by solid-state fermentation with three strains of Aspergillus.

\section{Experimental}

\subsection{Raw material and chemical characterization}

The waste samples were collected from industries in the area in season $2011 / 2012$ and stored at $-20{ }^{\circ} \mathrm{C}$. The solid residues were TPOMW, EGM, and VT. Their particle sizes were less than $1 \mathrm{~mm}$. The liquid wastes were $\mathrm{V}$ and OMWW. The solid residues were characterized by quantitative acid hydrolysis in a two-stage acid treatment (the first stage with $72 \mathrm{wt} \%$ sulfuric acid at $30^{\circ} \mathrm{C}$ for $1 \mathrm{~h}$ and the second stage after dilution of the medium to $4 \mathrm{wt} \%$ sulfuric acid at $121^{\circ} \mathrm{C}$ for $1 \mathrm{~h}$ ) to determine cellulose, hemicelluloses, and Klason lignin. Total nitrogen in liquid residues was determined by the test kit from Hach Lange LCK 338. For chemical oxygen demand (COD) determination, the test kit from Hach Lange LCK914 was used according the manufacturer's method. Total organic carbon in liquid residues was quantified by the test kit from Hach Lange LCK 387. Nitrogen and carbon in solid residues were analyzed using a Thermo Finningan Flash Elemental Analyzer 1112 series, San Jose, CA (USA). To determine free reducing sugars, total phenols, and proteins in solid residues, extraction with water 1:5 $(w / v)$ was performed. Reducing sugars were determined by dinitrosalicylic acid method. Lipids (total fat contents) were extracted with diethyl ether in a Soxtec System HT2 1045 extraction unit. Protein was determined by Bradford method. Total phenols were determined by the Folin-Ciocalteau method using caffeic acid as a standard. Total solids were analyzed by oven drying to a constant weight at $102{ }^{\circ} \mathrm{C}$. 


\subsection{Microorganisms}

Black Aspergillus species were used (A. niger 01UAs101, A. ibericus 01UAs294, and A. uvarum 01UAs128). They were obtained from MUM culture collection (Braga, Portugal). They were revived on malt extract agar (MEA) plates $(2 \%$ malt extract, $2 \%$ glucose, $0.1 \%$ peptone, and $2 \%$ agar) from preserved glycerol stocks stored at $-80{ }^{\circ} \mathrm{C}$, subcultured on MEA slants, and incubated at $25{ }^{\circ} \mathrm{C}$ for 7 days to obtain inocula for SSF. During the experimental period, strains were preserved at $4{ }^{\circ} \mathrm{C}$ and cultured monthly on fresh MEA slants.

\subsection{Solid-state fermentation}

Fermentations were carried out in a 500-mL Erlenmeyer flask with $30 \mathrm{~g}$ of dry solid substrate. Compositions of media were defined in Table 1. Moisture level was adjusted to $75 \%$. Erlenmeyers with substrate were sterilized at $121{ }^{\circ} \mathrm{C}$, for $15 \mathrm{~min}$. Independent fermentations were performed with A. niger, A. ibericus, and A. uvarum. For the inoculation, spores of fungus grown in MEA medium slant tubes were suspended in a sterilized solution composed of $0.1 \%$ of peptone and $0.01 \%$ of Tween 80 . The inoculum spore concentrations were adjusted to $10^{6}$ spores/ $\mathrm{mL}$ using a Neubauer counting chamber. Each flask was inoculated with $2 \mathrm{~mL}$ of the spore suspension and incubated at $25^{\circ} \mathrm{C}$ for 7 or 14 days.

The extraction of enzymes was performed at final time (7 or 14 days) of each experiment with a solution composed of $1 \% \mathrm{NaCl}$ and $0.5 \%$ Triton-X100 at $4{ }^{\circ} \mathrm{C}$, with agitation for $2 \mathrm{~h}$. Following, extracts were centrifuged (12, $225 \times \mathrm{g}, 10 \mathrm{~min})$ and filtered through a Whatman no. 1 filter paper.
2.4 Plackett-Burman experimental design

To evaluate the effect of supplementation of TPOMW on the enzyme productions by SSF, seven independent variables were screened in eight combinations (Table 1) organized according to the Plackett-Burman design. This is a fraction of a two-level factorial design and allows investigation of $n-1$ variables with at least $n$ experiments. The levels +1 and -1 represent the lower and the higher values of the process parameters. In addition, three center points were added to the eight experiments to ensure enough degrees of freedom for error evaluation. Experiments were carried out in randomize order to avoid protection against the effects of lurking variables. The factors were addition of EGM, VT, OMWW, V, basal medium, urea, and fermentation time. Xylanase, cellulose, and feruloyl esterase activities were taken as the responses. The factors that have confidence level above $95 \%$ were considered the most significant factors affecting enzyme production. The main effect of the substrate composition, regression coefficients, $P$ values, and correlation coefficients were determined using Statistica version 5.0 (Statsoft, USA).

\subsection{Enzyme activity assays of SSF extracts}

Cellulase (endo-1,4-ß-glucanase) activity was determined with the enzymatic kit Azo-CM-Cellulose S-ACMC 04/07 (Megazyme International, Ireland). One unit of enzyme activity was defined as the amount of enzyme required to release $1 \mu \mathrm{mol}$ of glucose reducing sugar equivalents from CMCellulose in $1 \mathrm{~min}$ at $40^{\circ} \mathrm{C}$ and $\mathrm{pH} 4.5$.

Xylanase (endo-1,4- $\beta$-xylanase) activity was determined with the enzymatic kit Azo wheat arabinoxylan AWX 10/ 2002 (Megazyme International, Ireland). One unit of enzyme activity was defined as the amount of enzyme

Table 1 Experiments of Plackett-Burman design

\begin{tabular}{|c|c|c|c|c|c|c|c|}
\hline Runs & \multicolumn{7}{|c|}{ Uncodded (codded values) } \\
\hline 1 & $1(+1)$ & $1(+1)$ & $0.5(+1)$ & $0.5(+1)$ & $0.5(+1)$ & $0.01(+1)$ & $14(+1)$ \\
\hline 2 & $1(+1)$ & $1(+1)$ & $0(-1)$ & $0.5(+1)$ & $0(-1)$ & $0(-1)$ & $7(-1)$ \\
\hline 3 & $1(+1)$ & $0(-1)$ & $0.5(+1)$ & $0(-1)$ & $0.5(+1)$ & $0(-1)$ & $7(-1)$ \\
\hline 4 & $1(+1)$ & $0(-1)$ & $0(-1)$ & $0(-1)$ & $0(-1)$ & $0.01(+1)$ & $14(+1)$ \\
\hline 5 & $0(-1)$ & $1(+1)$ & $0.5(+1)$ & $0(-1)$ & $0(-1)$ & $0.01(+1)$ & $7(-1)$ \\
\hline 6 & $0(-1)$ & $1(+1)$ & $0(-1)$ & $0(-1)$ & $0.5(+1)$ & $0(-1)$ & $14(+1)$ \\
\hline 7 & $0(-1)$ & $0(-1)$ & $0.5(+1)$ & $0.5(+1)$ & $0(-1)$ & $0(-1)$ & $14(+1)$ \\
\hline 8 & $0(-1)$ & $0(-1)$ & $0(-1)$ & $0.5(+1)$ & $0.5(+1)$ & $0.01(+1)$ & $7(-1)$ \\
\hline
\end{tabular}

All data are expressed per gram of dry solid substrate

EGM exhausted grape marc, TPOMW two-phase olive mill waste, $O M W W$ olive mill wastewater, VTS vineshoot trimmings

${ }^{a}$ Basal medium: $3 \mathrm{~g} / \mathrm{L} \mathrm{NaNO}_{3}, 1 \mathrm{~g} / \mathrm{L} \mathrm{K}_{2} \mathrm{HPO}_{4}, 0.5 \mathrm{~g} / \mathrm{L} \mathrm{KCl}, 0.5 \mathrm{~g} / \mathrm{L} \mathrm{MgSO} \cdot 7 \mathrm{H}_{2} \mathrm{O}, 0.5 \mathrm{~g} / \mathrm{L} \mathrm{CaCl}_{2} \cdot 2 \mathrm{H}_{2} \mathrm{O}, 1 \mathrm{~mL} / \mathrm{L}$ of trace metal solution, $0.1 \mathrm{~g} / \mathrm{L}$ peptone, $0.1 \mathrm{~g} / \mathrm{L}$ yeast extract 
required to release $1 \mu \mathrm{mol}$ of xylose reducing sugar equivalents from wheat arabinoxylan in $1 \mathrm{~min}$ at $40{ }^{\circ} \mathrm{C}$ and $\mathrm{pH}$ 4.5 .

Feruloyl esterase activity was determined according to Mastihuba et al. [24]. Enzyme extracts from SSF (3 mL) were mixed with $9 \mathrm{~mL}$ of $1.33 \mathrm{mM}$ ethyl ferulate in $50 \mathrm{mM}$ sodium phosphate buffer $(\mathrm{pH} 6)$ with $1 \%(w / v)$ ethanol. The reaction was incubated at $40{ }^{\circ} \mathrm{C}$ for $30 \mathrm{~min}$. A solution of $0.35 \mathrm{M}$ $\mathrm{H}_{2} \mathrm{SO}_{4}(4 \mathrm{~mL})$ was added to stop the reaction. The samples were filtered and the free ferulic acid was measured by highperformance liquid chromatographic (HPLC) with UV absorbance detection. One unit of enzyme activity was defined as the amount of enzyme required to release $1 \mu \mathrm{mol}$ of ferulic acid per minute, under the assay conditions.

Laccase activity was determined by spectophotometric method [25]. This method is based on monitoring the oxidation of 2,2'-azino-bis(3-ethylbenzothiazoline-6-sulphonic acid) (ABTS) by measuring the increase of absorbance at $420 \mathrm{~nm}$. One unit of laccase activity corresponded to oxidation of $1 \mu \mathrm{mol}$ of ABTS per minute at $25^{\circ} \mathrm{C}$.

Lignin peroxidase activity was quantified by the method proposed by Cai and Tien [26]. One unit of lignin peroxidase activity represented the oxidation of $1 \mu \mathrm{mol}$ of veratryl alcohol per minute at $30^{\circ} \mathrm{C}$.

$\mathrm{Mn}$ peroxidase activity was determined by oxidation of $\mathrm{Mn}^{2+}$ to $\mathrm{Mn}^{3+}$, measuring the increase of absorbance at $270 \mathrm{~nm}$ [27]. One unit of Mn peroxidase activity was defined as the amount of enzyme that produced $1 \mu \mathrm{mol}$ of $\mathrm{Mn}^{+3}$ per minute at $25^{\circ} \mathrm{C}$.

\subsection{HPLC analytical methods}

Glucose, xylose, arabinose, and acetic acid were measured using HPLC system. Chromatographic separation was carried out using a Metacarb $87 \mathrm{H}$ column $(300 \times 7.8 \mathrm{~mm}, 8$ $10 \mu \mathrm{m}$, Varian, USA) under the following conditions: mobile phase, $0.005 \mathrm{M} \mathrm{H}_{2} \mathrm{SO}_{4}$; flow rate, $0.7 \mathrm{~mL} / \mathrm{min}$; and column temperature, $60{ }^{\circ} \mathrm{C}$. The system was comprised of a Jasco chromatograph 880-PU intelligent pump (Jasco, Tokyo, Japan) equipped with a Jasco 830-IR intelligent refraction index detector (Jasco, Tokyo, Japan) and a Jasco AS-2057 Plus intelligent autosampler (Jasco, Tokyo, Japan).

Ferulic acid was determined by HPLC model 1200 (Agilent, Palo Alto, CA, USA), using a UV detector (at $276 \mathrm{~nm}$ ) and a quaternary pump. Separation was achieved at $35{ }^{\circ} \mathrm{C}$ using Zorbax SB-Aq reverse-phase column (4.6 mm ID $\times 150 \mathrm{~mm}, 5 \mu \mathrm{m}$, Agilent, Palo Alto, CA, USA) with a guard column and a linear gradient run in $35 \mathrm{~min}$ from 100 to $52 \%$ of $\mathrm{A}$ at a flow rate of $1 \mathrm{~mL} / \mathrm{min}$ consisting of two solvents: solvent A (2.5\% formic acid in water, $v / v)$ and solvent B (100\% methanol).

\section{Results and discussion}

\subsection{Agro-industrial waste characterization}

The nature of agro-industrial wastes affects the growth of fungi in SSF. Depending on their composition, microorganisms can produce specific products. Carbon and nitrogen sources are the most important components and should be given significant consideration [28]. The ratio between the mass of carbon and nitrogen is often optimized for the production of certain products as enzymes [29, 30]. Table 2 shows the composition of winery wastes (VT, EGM, V) and olive mill wastes (TPOMW, OMWW). TPOMW presented low nitrogen content and high concentration of phenolic compounds that can inhibit fungal growth [31]. Reducing sugar concentration was low in EGM because most of them are consumed in alcoholic fermentation during winemaking. The high organic content (high COD) of OMWW is also noteworthy that is why biological treatments are needed to reduce its pollutant load [32]. Lignocellulosic residues are excellent substrates for fungal growth in SSF [33]. Lignocellulose may be a substrate for the production of value-added products, such as biofuels, biochemicals, and enzymes [2]. Cellulose, hemicelluloses, and lignin present in these wastes can induce the production of lignocellulolytic enzymes [34]. VTS showed higher cellulose content which can induce the production of cellulases by fungi. TPOMW had a low cellulose and hemicellulose content; therefore, it is necessary to mix with other waste to improve the production of LCE. Vinasses can be a good source of $\mathrm{N}$ and minerals, and their use as a nutritional supplement for submerged fermentations has already been tested [35].

For this reason, it was considered that it could be interesting to mix TPOMW with other residues in order to reduce the concentration of phenolic compounds and to counteract the lack of nitrogen.

\subsection{Screening of substrate composition for SSF using a Placket-Burman design}

In this study, selected fungi were inoculated on winery and olive oil mill waste for production of enzymes by SSF. In initial tests, a poor growth of fungi on TPOWM was observed (data not shown). In other work, A. niger also exhibited slower growth on TPOWM than on sugar beet waste and rice hulls [36]. Additionally, Aloui et al. [37] observed that $A$. niger was inhibited by TPOMW, but the mixtures of TPOMW with sugarcane bagasse clearly increased the fungal growth. This strong inhibition was probably caused by the high initial concentration of phenolic compounds. In composting processes of TPOWM, long composting periods are needed for this kind of material due to the presence of fats and phenols [38]. The use of other wastes could stimulate the growth of fungi 
Table 2 Main characteristics of solid wastes from wineries and olive oil industries
TPOMW two-phase olive mil waste, $O M W W$ olive mill wastewater, TOC total organic carbon, $C O D$ chemical oxygen demand

${ }^{\text {a }}$ In aqueous extract

\begin{tabular}{|c|c|c|c|}
\hline & Solid wastes & & \\
\hline Parameters & TPOMW & Vineshoot trimmings & Exhausted grape marc \\
\hline $\mathrm{C}(\mathrm{g} / \mathrm{kg})$ & $516.61 \pm 15.43$ & $453.56 \pm 2.21$ & $482.37 \pm 16.07$ \\
\hline $\mathrm{N}(\mathrm{g} / \mathrm{kg})$ & $8.59 \pm 1.92$ & $5.62 \pm 0.71$ & $16.97 \pm 6.26$ \\
\hline $\mathrm{C} / \mathrm{N}$ & 60.16 & 80.76 & 28.42 \\
\hline Cellulose (g/100 g) & $6.76 \pm 0.24$ & $29.56 \pm 0.03$ & $14.37 \pm 0.01$ \\
\hline Hemicelluloses (g/100 g) & $4.18 \pm 0.21$ & $9.73 \pm 0.01$ & $5.84 \pm 0.01$ \\
\hline Klason lignin (g/100 g) & $58.16 \pm 0.41$ & $37.34 \pm 0.02$ & $57.67 \pm 0.01$ \\
\hline Reducing sugars (mg/g) & $24.30 \pm 1.42$ & $55.35 \pm 0.05$ & $3.00 \pm 0.01$ \\
\hline Protein (mg/g) & $0.30 \pm 0.03$ & $1.27 \pm 0.03$ & $1.30 \pm 0.00$ \\
\hline Total phenols ${ }^{\mathrm{a}}$ (mg/g) & $2.57 \pm 0.04$ & $1.25 \pm 0.04$ & $0.19 \pm 0.01$ \\
\hline Lipids (mg/g) & $102.46 \pm 0.04$ & $29.6 \pm 0.00$ & $21.3 \pm 0.00$ \\
\hline \multirow[t]{2}{*}{ Moisture (\%) } & $75.31 \pm 0.14$ & $6.08 \pm 0.09$ & $11.03 \pm 0.12$ \\
\hline & Liquid wastes & & \\
\hline Parameters & Vinasses & & OMWW \\
\hline Nitrogen (mg/L) & $218.67 \pm 35.27$ & & $5.2 \pm 0.2$ \\
\hline TOC $(g / L)$ & $3.53 \pm 0.02$ & & $21.4 \pm 1.2$ \\
\hline $\mathrm{COD}(\mathrm{g} / \mathrm{L})$ & $48.07 \pm 1.43$ & & $122.9 \pm 0.42$ \\
\hline Reducing sugars (g/L) & $0.68 \pm 0.01$ & & $12.7 \pm 1.3$ \\
\hline Protein $(g / L)$ & $0.31 \pm 0.08$ & & $0.04 \pm 0.01$ \\
\hline Lipids (g/L) & - & & $4.1 \pm 0.42$ \\
\hline Total phenols (mg/L) & $0.54 \pm 0.03$ & & $5.91 \pm 0.09$ \\
\hline Total solids (\%) & $2.24 \pm 0.09$ & & $15.43 \pm 0.51$ \\
\hline
\end{tabular}

and the production of enzymes on SSF processes with TPOMW because it could improve the transfer of oxygen and reduce toxicity [37].

To evaluate the effect of TPOMW mixture with other agroindustrial by-products in SSF, a Plackett-Burman experimental design was performed. This design assumes that there are no interactions between the different media components $\left(x_{\mathrm{i}}\right)$ in the range of variables under consideration. The following first-order polynomial model was used to describe the results:

$Y=\beta_{0}+\sum \beta_{\mathrm{i}} \cdot x_{\mathrm{i}}$

where $Y$ is the response value, $\beta_{0}$ is the model intercept, $\beta_{\mathrm{i}}$ is the linear coefficient, and $x_{\mathrm{i}}$ is the level of the independent variable.

An experimental design for each microorganism was performed; designs were applied with 11 different fermentation conditions as shown in Table 1. This design allowed evaluating the main effect of EGM, OMWW, V, nutrients, urea addition, and time upon enzyme production by SSF.

Several enzyme activities were determined in extracts: cellulases, xylanases, feruloyl esterases, laccases, Mn peroxidases, and lignin peroxidases. Table 3 presents main enzyme activities detected in extract from SSF of the three selected fungal strains. In general, a wide variation can be observed in enzyme activities reported. This variation shows the influence of substrate composition and the importance of medium selection to attain a higher production of enzymes. Table 4 shows the coefficients of regression and coefficients of determination $\left(R^{2}\right)$ of each design. Significant coefficients were identified by an asterisk $(*)$. Regression coefficients allow the determination of the effect of each constituent. A high value of regression coefficient indicates that a factor has a large impact on dependent variable. A $R^{2}$ close to 1 indicates a good correlation between the predicted response value and the actual response value. A possible curvature effect was included in the model.

\subsection{Lignocellulolytic activity}

Comparing LCE production from three different fungi, $A$. niger showed higher activity of FAEs and xylanases, while A. uvarum attained the best cellulase activity. The mixture of three solid residues presented the maxima lignocellulolytic activities.

\subsubsection{FAE activity}

A. niger was the most suitable fungi for FAE production. A maximum activity of $89.53 \mathrm{U} / \mathrm{g}$ was attained in experiment 1 (Table 3). Strains of Aspergillus section Nigri were capable of producing FAEs [23], and $\mathrm{Ou}$ et al. [39] tested the production of FAEs from $A$. niger by SSF. They achieved a maximum activity of $7.68 \mathrm{mU} / \mathrm{g}$ using mixtures of maize bran and wheat 
Table 3 Enzyme activities of experiments with PlackettBurman design

Units are expressed as units per gram of dry solid substrate

$C A$ cellulase activity, $X A$ xylanase activity, $F E A$ feruloyl esterase activity

\begin{tabular}{|c|c|c|c|c|c|c|c|c|}
\hline \multirow[t]{2}{*}{ Runs } & \multicolumn{3}{|c|}{ Aspergillus niger } & \multicolumn{3}{|c|}{ Aspergillus ibericus } & \multicolumn{2}{|c|}{ Aspergillus uvarum } \\
\hline & $\mathrm{CA}$ & XA & FEA & $\mathrm{CA}$ & XA & FEA & $\mathrm{CA}$ & XA \\
\hline 1 & 5.20 & 2.30 & 89.53 & 5.50 & 1.52 & 12.09 & 6.77 & 0.49 \\
\hline 2 & 0.00 & 0.05 & 0.00 & 0.00 & 0.15 & 0.00 & 0.02 & 0.04 \\
\hline 3 & 0.08 & 0.02 & 0.00 & 0.00 & 0.11 & 0.00 & 0.06 & 0.03 \\
\hline 4 & 3.36 & 2.52 & 58.05 & 3.76 & 1.74 & 7.49 & 4.50 & 0.39 \\
\hline 5 & 1.80 & 3.06 & 8.51 & 1.33 & 1.34 & 5.90 & 2.36 & 0.11 \\
\hline 6 & 0.10 & 0.03 & 0.00 & 0.03 & 0.05 & 0.00 & 0.02 & 0.09 \\
\hline 7 & 0.11 & 0.06 & 0.00 & 0.10 & 0.13 & 0.00 & 0.01 & 0.00 \\
\hline 8 & 1.79 & 1.65 & 32.10 & 1.90 & 0.95 & 0.51 & 1.54 & 0.00 \\
\hline 9 & 1.73 & 0.42 & 21.45 & 2.08 & 0.213 & 0.21 & 3.00 & 0.08 \\
\hline 10 & 1.62 & 0.35 & 18.34 & 2.03 & 0.395 & 0.18 & 3.35 & 0.15 \\
\hline 11 & 1.60 & 0.38 & 20.51 & 1.96 & 0.133 & 0.23 & 3.49 & 0.17 \\
\hline
\end{tabular}

bran. FAE production by SSF was also tested using sugar beet pulp as a solid support, and a maximum activity of $5 \mathrm{nkat} / \mathrm{g}$ (equivalent to $0.3 \mu \mathrm{mol}$ of ferulic acid released per minute) was attained on optimal conditions [40]. Figure 1a shows a clear positive effect of urea addition to the fermentation medium. Urea is an organic nitrogen source widely used in biotechnology processes for its low cost. Ou et al. [39] observed that urea and $\left(\mathrm{NH}_{4}\right)_{2} \mathrm{SO}_{4}$ were the best sources of nitrogen for FAE production from $A$. niger in mixtures of wheat bran with maize bran and sugarcane bagasse. Moreover, the use of EGM as substrate for SSF also proved effective for the production of FAEs.

FAE activity was also observed from $A$. ibericus, but not from $A$. uvarum (Table 3 ). In Table 4, it can be observed that all factors had a significant effect at $95 \%$ on FAE production by $A$. ibericus. It has been demonstrated the potential use of this strain for lipase production [41]; however, their use in the LCE production such as FAEs was not proven.

\subsubsection{Cellulase activity}

The three studied strains showed endocellulase activity, and maximum activity was achieved with $A$. uvarum $(6.77 \mathrm{U} / \mathrm{g}$ dry substrate) mixing all solid residue TPOMW, EGM, and VT, after 14 days of fermentation. Thus, it was observed that these solid wastes can induce endocellulase production in SSF. In another work, A. japonicus, morphologically close to $A$. uvarum, was used in different substrates and a maximum cellulase activity of $19.38 \mathrm{U} / \mathrm{g}$ in wheat bran substrate was observed [42]. So far, no studies on the production of LCEs by A. uvarum were found. Figure $1 \mathrm{~b}$ displays the main effects of substrate composition and time of fermentation on endocellulase activity. Urea and EGM were principal factors that positively influence the endocellulase activity. The effect of OMWW and nutrient supplementation was not significant at $95 \%$; however, the addition of $\mathrm{V}$ was significantly positive at $95 \%$. Longer fermentation times favored endocellulase
Table 4 Regression coefficients for enzyme activities of $A$. niger, A. ibericus, and A. uvarum

\section{$C A$ cellulase activity, $X A$} xylanase activity, $F E A$ feruloyl esterase activity

${ }^{a}$ Significant coefficient at the $95 \%$

\begin{tabular}{|c|c|c|c|c|c|c|c|c|}
\hline \multirow[t]{2}{*}{ Terms } & \multicolumn{3}{|c|}{ Aspergillus niger } & \multicolumn{3}{|c|}{ Aspergillus ibericus } & \multicolumn{2}{|c|}{ Aspergillus uvarum } \\
\hline & $\mathrm{CA}$ & $\mathrm{XA}$ & FEA & $\mathrm{CA}$ & XA & FEA & $\mathrm{CA}$ & XA \\
\hline Constant & $1.555^{\mathrm{a}}$ & $1.209^{\mathrm{a}}$ & $23.524^{\mathrm{a}}$ & $1.578^{\mathrm{a}}$ & $0.748^{\mathrm{a}}$ & $3.248^{\mathrm{a}}$ & $1.909^{\mathrm{a}}$ & $0.143^{\mathrm{a}}$ \\
\hline Curvature & 0.095 & $-0.828^{\mathrm{a}}$ & -3.424 & $0.446^{\mathrm{a}}$ & $-0.501^{\mathrm{a}}$ & $-3.042^{\mathrm{a}}$ & $1.365^{\mathrm{a}}$ & -0.018 \\
\hline EGM & $0.605^{\mathrm{a}}$ & 0.012 & $13.372^{\mathrm{a}}$ & $0.738^{\mathrm{a}}$ & 0.131 & $1.647^{\mathrm{a}}$ & $0.928^{\mathrm{a}}$ & $0.094^{\mathrm{a}}$ \\
\hline VT & $0.22^{\mathrm{a}}$ & $0.150^{\mathrm{a}}$ & 0.986 & $0.138^{\mathrm{a}}$ & 0.016 & $1.249^{\mathrm{a}}$ & $0.384^{\mathrm{a}}$ & 0.039 \\
\hline OMWW & $0.243^{\mathrm{a}}$ & $0.149^{\mathrm{a}}$ & 0.986 & $0.155^{\mathrm{a}}$ & 0.026 & $1.249^{\mathrm{a}}$ & 0.174 & -0.01 \\
\hline Vinasses & $0.22^{\mathrm{a}}$ & $-0.196^{\mathrm{a}}$ & $6.884^{\mathrm{a}}$ & $0.298^{\mathrm{a}}$ & -0.062 & $-0.099^{\mathrm{a}}$ & $0.390^{\mathrm{a}}$ & 0.014 \\
\hline Nutrients & $0.234^{\mathrm{a}}$ & $-0.213^{\mathrm{a}}$ & $6.884^{\mathrm{a}}$ & $0.28^{\mathrm{a}}$ & -0.091 & $-0.099^{\mathrm{a}}$ & 0.187 & 0.009 \\
\hline Urea & $1.483^{\mathrm{a}}$ & $1.172^{\mathrm{a}}$ & $23.523^{\mathrm{a}}$ & $1.545^{\mathrm{a}}$ & $0.639^{\mathrm{a}}$ & $3.248^{\mathrm{a}}$ & $1.882^{\mathrm{a}}$ & $0.104^{\mathrm{a}}$ \\
\hline Time & $0.6375^{\mathrm{a}}$ & 0.016 & $13.372^{\mathrm{a}}$ & $0.77^{\mathrm{a}}$ & 0.111 & $1.648^{\mathrm{a}}$ & $0.914^{\mathrm{a}}$ & $0.01^{\mathrm{a}}$ \\
\hline$R^{2}$ & 0.9996 & 0.9998 & 0.9994 & 0.9998 & 0.9914 & 0.9999 & 0.9974 & 0.9807 \\
\hline$R^{2}$ corrected & 0.9981 & 0.9992 & 0.9969 & 0.9988 & 0.9570 & 0.9999 & 0.9870 & 0.9035 \\
\hline
\end{tabular}



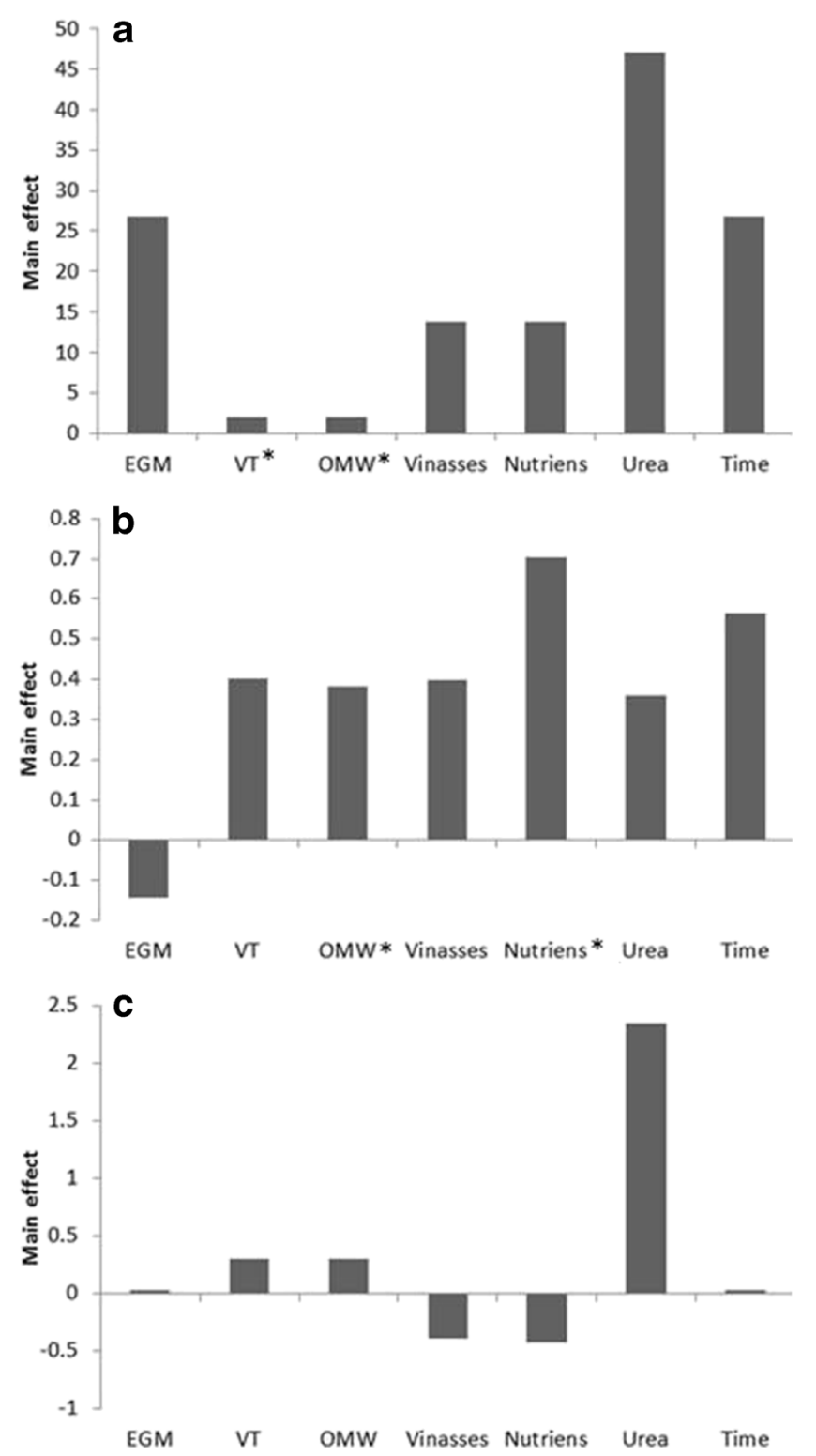

Fig. 1 The main effects of the substrate composition on a feruloyl esterase activity from $A$. niger, b cellulase activity from $A$. uvarum, and c xylanase activity from $A$. niger. Asterisk represents not significant variables

production; this may be due to the need of a prior action of the xylanases to expose the cellulose fibers, which will induce cellulase production. With Aspergillus awamori, xylanase activity was detected at the beginning of fermentation, then cellulase activity increased rapidly and maximum activity remained several days, but the xylanase activity declined rapidly [43]. Production of cellulases by other fungi as Trichoderma spp. has been widely studied. Cellulases and hemicellulases from Trichoderma reesei are the most commonly used in industry [44]. Florencio et al. [45] studied the production of endocellulases by different strains of Trichoderma (Trichoderma harzianum and T. reesei RUT C30) using sugarcane bagasse and wheat bran and observed that mutant strain (T. reesei RUT C30) showed higher activity $(70.24 \mathrm{UI} / \mathrm{g})$ than the other strains $(18-25 \mathrm{UI} / \mathrm{g})$.

\subsubsection{Xylanase activity}

Table 3 shows that $A$. niger achieved maximum endoxylanase activity (3.06 U/g of dry substrate) in run 5 . It is common to use $A$. niger to produce xylanase. Kavya et al. [46] observed a maximum xylanase activity of $12.65 \mathrm{U} / \mathrm{mL}$ on wheat bran as a substrate. However, Trichoderma longibrachiatum is the most commonly used, which achieved high xylanase activities [47]. Endoxylanase production benefited from a strong effect of urea addition (Fig. 1c). Accordingly, a positive effect of urea in enzyme production has been observed in other works; xylanase activity was increased with urea and other nitrogen source in SSF by A. niger [48]. Accordingly, urea was recognized as the suitable nitrogen source along with yeast extract and $\mathrm{NaNO}_{3}$ [49]. The effect of time and mixture of TPOMW with EGM were not significant at $95 \%$. Usually, short fermentation times are needed for xylanase production by SSF. $\mathrm{Xu}$ et al. [49] achieved maximum activity at $48 \mathrm{~h}$. The lower endoxylanase activity detected in our study may be due to the lost activity in consequence of fermentation times used, 7 or 14 days.

Endoxylanases from A. ibericus and A. uvarum showed lower activity than $A$. niger. However, it is common to use enzyme cocktails with xylanase and cellulase activities for paper pulp industry [50]. Thereby, suitable strains for cellulase production like $A$. uvarum can have industrial interest, despite having a reduced production of xylanases.

\subsubsection{Ligninase activity}

Other enzymes were detected in some experiments. In the media with TPOMW, VT, OMWW, and urea (experiment 5) fermented by $A$. niger, a low activity of Mn peroxidases, laccases, and lignin peroxidases $(0.64,2.47$, and $0.18 \mathrm{U} / \mathrm{g}$ of dry substrate) was observed. These enzymes can degrade lignocellulosic materials and, in addition, recalcitrant environmental pollutants, such as crude oil wastes, textile effluents, organochloride agrochemicals, and pulp effluents [51]. White rot fungi are the most common producers of laccases. Trametes versicolor is a good producer of laccases. In the SSF of corn stover, $T$. versicolor achieved a high laccase acivity (45.1 IU/g) under the optimized conditions; however, low xylanase and endocellulase and no Mn peroxidase and lignin peroxidase activity was detected [52].

\section{Conclusions}

Different enzymes were produced according to the substrate used. Mixture of olive mill wastes with winery wastes favors 
the production of endocellulases, endoxylanases, and feruloyl esterases. The effect of each waste on LCE production was studied by the Plackett-Burman experimental design. In all experimental designs, good determination coefficients close to 1 were obtained. A. niger was more effective in producing hemicellulase enzymes such as FAEs and endoxylanases, whereas, maximum endocellulase production was achieved by $A$. uvarum. Urea showed to have a significant effect on LCE production in the three strains. Longer times of fermentation improved endocelullase and FAE production, without affecting endoxylanase production. In general, all mixtures of winery and olive mill wastes were suitable substrates for SSF. Thereby, the SSF of these wastes can be an interesting approach for its valorization.

Acknowledgments José Manuel Salgado is grateful for the postdoctoral fellowship (EX-2010-0402) of the Education Ministry of Spanish Government. Luís Abrunhosa was supported by the grant SFRH/BPD/ 43922/2008 from Fundação para a Ciência e Tecnologia-FCT, Portugal.

\section{References}

1. Deswal D, Sharma A, Gupta R, Kuhad RC (2012) Application of lignocellulolytic enzymes produced under solid state cultivation conditions. Bioresour Technol 115:249-254

2. Tengerdy RP, Szakacs G (2003) Bioconversion of lignocellulose in solid substrate fermentation. Biochem Eng J 13:169-179

3. Tao L, Aden A, Elander RT, Pallapolu VR, Lee YY, Garlock RJ, Balan Vet al (2011) Process and technoeconomic analysis of leading pretreatment technologies for lignocellulosic ethanol production using switchgrass. Bioresour Technol 102(24):11105-11114

4. Brijwani K, Oberoi HS, Vadlani PV (2010) Production of a cellulolytic enzyme system in mixed-culture solid-state fermentation of soybean hulls supplemented with wheat bran. Process Biochem 45(1):120-128

5. Zimbardi ALRL, Sehn C, Meleiro LP, Souza FHM, Masui DC, Nozawa MSF, Guimarães LHS, Jorge JA, Furriel RPM (2013) Optimization of $\beta$-glucosidase, $\beta$-xylosidase and xylanase production by Colletotrichum graminicola under solid-state fermentation and application in raw sugarcane trash saccharification. Int J Mol Sci 14(2):2875-2902

6. Ali HKQ, Zulkali MMD (2011) Design aspects of bioreactors for solid-state fermentation: a review. Chem Biochem Eng Q 25(2):255266

7. Prévot V, Lopez M, Copinet E, Duchiron F (2013) Comparative performance of commercial and laboratory enzymatic complexes from submerged or solid-state fermentation in lignocellulosic biomass hydrolysis. Bioresour Technol 129:690-693

8. Obruca S, Marova I, Matouskova P, Haronikova A, Lichnova A (2012) Production of lignocellulose-degrading enzymes employing Fusarium solani F-552. Folia Microbiol 57(3):221-227

9. Taherzadeh MJ, Karimi K (2008) Pretreatment of lignocellulosic wastes to improve ethanol and biogas production: a review. Int $\mathrm{J}$ Mol Sci 9:1621-1651

10. Durand A (2003) Bioreactor designs for solid state fermentation. Biochem Eng J 13:113-125

11. Tabka MG, Herpoël-Gimbert I, Monod F, Asther M, Sigoillot JC (2006) Enzymatic saccharification of wheat straw for bioethanol production by a combined cellulase xylanase and feruloyl esterase treatment. Enzyme Microb Technol 39(4):897-902

12. Pothiraj C, Balaji P, Eyini M (2006) Enhanced production of cellulases by various fungal cultures in solid state fermentation of cassava waste. Afric J Biotechnol 5:1882-1885

13. Carvalho T, Paulo D, Gomes P, Cristina R, Bonomo F, Franco M (2012) Optimisation of solid state fermentation of potato peel for the production of cellulolytic enzymes. Food Chem 133(4):1299-1304

14. Perrone G, Varga J, Susca A, Frisvad JC, Stea G, Kocsubé S, Tóth B, Kozakiewicz Z, Samson RA (2008) Aspergillus uvarum sp. nov., an uniseriate black Aspergillus species isolated from grapes in Europe. Int J Syst Evol Micr 58:1032-1039

15. Facchini FDA, Vici AC, Reis VRA, Jorge JA, Terenzi HF, Reis RA, Polizeli MLTM (2011) Production of fibrolytic enzymes by Aspergillus japonicus $\mathrm{C} 03$ using agro-industrial residues with potential application as additives in animal feed. Bioproc Biosyst Eng 34(3): 347-355

16. Herculano PN, Porto TS, Moreira KA, Pinto GAS, Souza-Motta CM, Porto ALF (2011) Cellulase production by Aspergillus japonicus URM5620 using waste from castor bean (Ricinus communis L.) under solid-state fermentation. Appl Biochem Biotech 165(3-4): 1057-1067

17. Shallom D, Shoham Y (2003) Microbial hemicellulases. Curr Opin Microbiol 6(3):219-228

18. Collins T, Gerday C, Feller G (2005) Xylanases, xylanase families and extremophilic xylanases. FEMS Microbiol Rev 29(1):3-23

19. Jeffries TW (1994) Biodegradation of lignin and hemicelluloses. In: Ratledge C (ed) Biochemistry of microbial degradation. Springer, Dordrecht, pp 233-277

20. Sapag A, Wouters J, Lambert C, de Ioannes P, Eyzaguirre J, Depiereux E (2002) The endoxylanases from family 11: computer analysis of protein sequences reveals important structural and phylogenetic relationships. J Biotechnol 95:109-131

21. Wong DWS (2006) Feruloyl esterase. A key enzyme in biomass degradation. Appl Biochem Biotech 133:87-112

22. Bonnin E, Saulnier L, Brunel M, Marot C, Lesage-meessen L, Asther M, Thibault (2002) Release of ferulic acid from agroindustrial byproducts by the cell wall-degrading enzymes produced by Aspergillus niger I-1472. Enzyme Microb Tech 31:1000-1005

23. Bouzid O, Record E, Asther M, Haon M, Navarro D, Asther M, Lesage-Meessen L (2006) Exploration of members of Aspergillus sections Nigri, Flavi, and Terrei for feruloyl esterase production. Can J Microbiol 52:886-892

24. Mastihuba V, Kremnicky L, Mastihubová M, Willett JL, Coté GL (2002) A spectrophotometric assay for feruloyl esterases. Anal Biochem 309:96-101

25. Pazarlığlu NK, Sariişik M, Telefoncu A (2005) Laccase: production by Trametes versicolor and application to denim washing. Process Biochem 40(5):1673-1678

26. Cai D, Tien M (1991) Lignin peroxidase of Phanerochaete chrysosporium. J Biol Chem 266:14464-14469

27. Giardina P, Palmieri G, Fontanella B, Rivieccio V, Sannia G (2000) Manganese peroxidase isoenzymes produced by Pleurotus ostreatus grown on wood sawdust. Arch Biochem Biophys 376(1):171-179

28. Rodríguez-Leon JA, Soccol CR, Pandey A, Rodríguez DE (2008) Factors affecting soli-state fermentation. In: Current developments in solid-state fermentation. Springer, New York, pp 26-47

29. Gombert AK, Pinto AL, Castilho LR, Freire DMG (1999) Lipase production by Penicillium restrictum in solid-state fermentation using babassu oil cake as substrate. Process Biochem 35:85-90

30. Bertolin TE, Schmidell W, Maiorano AE, Casara J, JaV C (2003) Influence of carbon, nitrogen and phosphorous sources on glucoamylase production by Aspergillus awamori in solid state fermentation. Z Naturforsch 58:708-712

31. Medina E, Romero C, de los Santos B, de Castro A, Garcia A, Romero F, Brenes M (2011) Antimicrobial activity of olive solutions 
from stored alpeorujo against plant pathogenic microorganisms. J Agric Food Chem 59(13):6927-6932

32. Khatib A, Aqra F, Yaghi NYS, Hayeek B, Musa M, Basheer S, Sabbah I (2009) Reducing the environmental impact of olive mill wastewater. Am J Environ Sci 5(1):1-6

33. Elisashvili V, Kachlishvili E, Penninckx M (2008) Effect of growth substrate, method of fermentation, and nitrogen source on lignocellulose-degrading enzymes production by white-rot basidiomycetes. J Ind Microbiol Biot 35(11):1531-1538

34. Chmelová D, Ondrejovič M, Ondáš V, Šturdík E (2011) Influence of cultivation conditions on production of lignocellulolytic enzymes by Ceriporiopsis subvermispora. Biologia 66:748-754

35. Salgado JM, Carballo EM, Max B, Domínguez JM (2010) Characterization of vinasses from five certified brands of origin (CBO) and use as economic nutrient for the xylitol production by Debaryomyces hansenii. Bioresour Technol 101(7):2379-2388

36. Vassilev N, Baca MT, Vassileva M, Franco I, Azcon R (1995) Rock phosphate solubilization by Aspergillus niger grown on sugar-beet waste medium. Appl Microbiol Biot 44:546-549

37. Aloui F, Abid N, Roussos S, Sayadi S (2007) Decolorization of semisolid olive residues of "alperujo" during the solid state fermentation by Phanerochaete chrysosporium, Trametes versicolor, Pycnoporus cinnabarinus and Aspergillus niger. Biochem Eng J 35(2):120-125

38. Cayuela ML, Sánchez-Monedero MA, Roig A (2010) Two-phase olive mill waste composting: enhancement of the composting rate and compost quality by grape stalks addition. Biodegradation 21(3): $465-473$

39. Ou S, Zhang J, Wang Y, Zhang N (2011) Production of feruloyl esterase from Aspergillus niger by solid-state fermentation on different carbon sources. Enzyme Res 2011:1-4

40. Asther M, Haon M, Roussos S, Record E, Delattre M, Lesagemeessen L, Labat M, Asther M (2002) Feruloyl esterase from Aspergillus niger a comparison of the production in solid state and submerged fermentation. Process Biochem 38:685-691

41. Abrunhosa L, Oliveira F, Dantas D, Gonçalves C, Belo I (2012) Lipase production by Aspergillus ibericus using olive mill wastewater. Bioprocess Biosyst Eng 36:285-291

42. Facchini FDA, Vici AC, Reis VRA, Jorge JA, Terenzi HF, Reis RA, Polizeli MLTM (2011) Production of fibrolytic enzymes by
Aspergillus japonicus $\mathrm{C} 03$ using agro-industrial residues with potential application as additives in animal feed. Bioprocess Biosyst Eng 34(3):347-355

43. Botella C, Ory ID, Webb C, Cantero D, Blandino A (2005) Hydrolytic enzyme production by Aspergillus awamori on grape pomace. Biochem Eng J 26(2-3):100-106

44. Druzhinina IS, Kopchinskiy AG, Kubicek CP (2006) The first 100 Trichoderma species characterized by molecular data. Mycoscience 47(2):55-64

45. Florencio C, Couri S, Farinas CS (2012) Correlation between agar plate screening and solid-state fermentation for the prediction of cellulase production by Trichoderma strains. Enzyme Res 2012:1-7

46. Kavya V, Padmavathi T (2009) Optimization of growth conditions for xylanase production by Aspergillus niger in solid state fermentation. Polish J Microbiol 58(2):125-130

47. Azin M, Moravej R, Zareh D (2007) Production of xylanase by Trichoderma longibrachiatum on a mixture of wheat bran and wheat straw: optimization of culture condition by Taguchi method. Enzyme Microb Tech 40(4):801-805

48. Liu C, Sun ZT, Du JH, Wang J (2008) Response surface optimization of fermentation conditions for producing xylanase by Aspergillus niger SL-05. J Ind Microbiol Biot 35(7):703-711

49. Xu YX, Li YL, Xu SC, Liu Y, Wang X, Tang JW (2008) Improvement of xylanase production by Aspergillus niger XY-1 using response surface methodology for optimizing the medium composition. J Zhejiang Univ Sci B 9(7):558-566

50. Das A, Paul T, Halder SK, Jana A, Maity C, Mohapatra PKD, Pati BR, Mondal KC (2013) Bioresource technology production of cellulolytic enzymes by Aspergillus fumigatus ABK9 in wheat bran-rice straw mixed substrate and use of cocktail enzymes for deinking of waste office paper pulp. Bioresour Technol 128:290-296

51. Mabrouk M, Kheiralla H, Hamed R, Youssry A, Aty AAE (2010) Screening of some marine-derived fungal isolates for lignin degrading enzymes (LDEs) production. Agric Biol J N Am 1:561599

52. Zhu Y, Zhang H, Zhang Y, Huang F (2011) Lignocellulose degradation, enzyme production and protein enrichment by Trametes versicolor during solid-state fermentation of corn stover. Afr J Biotechnol 10(45):9182-9192 